\title{
Quantum-Chemical Description of Influence of the R-Groups on Formation of Peptide Bond
}

\author{
Jumber Kereselidze ${ }^{1 *}$, Marine Kvaraia ${ }^{2}$, George Mikuchadze ${ }^{1}$ \\ ${ }^{1}$ I. Javakhishvili Tbilisi State University, Tbilisi, Georgia \\ ${ }^{2}$ Sukhumi State University, Tbilisi, Georgia \\ Email: “jumber.kereselidze@tsu.ge, mariqvaraia@yahoo.com,gmikuchadze@gmail.com
}

Received 4 July 2014; revised 3 August 2014; accepted 1 September 2014

Copyright @ 2014 by authors and Scientific Research Publishing Inc.

This work is licensed under the Creative Commons Attribution International License (CC BY). http://creativecommons.org/licenses/by/4.0/

(c) (i) Open Access

\begin{abstract}
The description of influence of the R-groups on formation of the peptide bond by quantum-chemical method of density functional theory (DFT) is carried out. The criterion of probability of formation of the peptide bond has been constructed. In particular it is shown that the propensity to formation of the peptide bond is increased as a result of 1 ) decrease of the $\mathrm{CO}$ and $\mathrm{NH}$ bond orders ( $P_{\mathrm{CO}}$ and $\left.\mathrm{P}_{\mathrm{NH}}\right)$ and of activation energy $\left.\left(\Delta \mathrm{E}^{\#}\right), 2\right)$ increase of $\mathrm{OH}$ and $\mathrm{CN}$ bond orders $\left(\mathrm{P}_{\mathrm{OH}}\right.$ and $\left.\left.\mathrm{P}_{\mathrm{CN}}\right), 3\right)$ exothermic property of this reaction $(\Delta \mathrm{E}<0)$.
\end{abstract}

\section{Keywords}

Amino Acids Sequence, Peptide Bond, DFT Calculations

\section{Introduction}

One of greatest scientific achievements of the 20th century is the creation of recognition of a sequence of amino acids in proteins [1]-[6]. Sanger in the researches used quantum-chemical methods, however on an early stage of development these methods for the description of an electronic structure of biomolecules did not give authentic results and consequently the researches have been at a morphological level. At the end of century W. Kohn and J. Pople have created a modern method of quantum chemistry-Density Functional Theory (DFT) [7]. It is known, that the sequence of amino acids in the polypeptide chain of protein is coded by the sequence of nucleotide residues of DNA. On the other hand R-groups by means of their inductive and spatial effects promote or impede formation of the peptide bonds between of the amino acids pair. This effect, unlike genetic coding, can be used

"Corresponding author. 
for the quantitative description of probability of formation of the peptide bonds. One may suppose, that these two phenomena do not contradict, but supplement each other. However the search of some quantitative correlation of given stage seems hopeless.

The detailed mechanism of the peptide bond synthesis that occurs on the large ribosomal subunit remains unknown. The most favorable mechanism is found not to involve any general acid-base catalysis by ribosomal groups but an intrareactant proton shuttling via the P-site adenine O2' oxygen, which follows the attack of the A-site-amino group of the P-site ester. The calculated rate enhancement for this mechanism is $\approx 10^{5}$, the catalystic effect is found to be entirely of entropic origin, in accordance with recent experimental data, and is associated with the reduction of solvent reorganization energy rather than with substrate alignment or proximity. This mechanism also explains the inability of 2'-deoxyadenine P-site substrates to promote peptidyl transfer. The observed H-bond network suggest an important structural of several universally conserved rRNA residues [8].

\section{Methods}

Density functional theory (DFT) [7] is a quantum-chemical modeling method used in physics and chemistry to investigate the electronic structure of many-body systems, in atoms, molecules, and the condensed phases. Within this theory, the properties of a many-electron system can be determined by using functionals to be which in this case is the spatially dependent electron density. Hence the name of density functional theory comes from the use of functionals of the electron density. DFT is among the most popular and versatile methods available in condensed-matter physics, computational physics, and computational chemistry. Using the B3LYP level of bases set [9]-[11] in the gas phase the complete geometry optimization. The calculation were performed by the "Priroda" software developed by Laikov and Ustinyuk [12] in the reaction coordinate.

\section{Results and Discussed}

With use of the DFT method computational model, which represent a criteria of probability of formation of the peptide bonds has been created. As known the synthesis of protein catalyzed by ribosome is complex biochemical process. The ribosome mainly provokes excitement of the C-O bond of the oxycarbonyle group with purpose of pairing with amino group of another amino acid. On the other hand it is necessary to consider influence of a structure of amino acids on formation of the peptide bonds, which as against of a catalise role of ribosome varies depending on inductive and spatial properties of R-groups.

On the basis of successes of the computer description of micro-processes, we count that with application of an offered method is possible to receive more important results for an every possible combination of a sequence of amino acids. Without exaggeration one can noted, what by these researches the new era of quantum biochemistry will begin.

The purpose of the planned research is describe an electronic structure (orders of the broken off and formed bonds) and energetic condition (energy of activation and energy of reaction of formation peptide bonds) of amino acids, participating during formation of a natural and man-made sequence.

By means of comparison of the received results we can quantitatively estimate the probability of the formation of polypeptides and influences of the R-groups on this process (Scheme 1).

By object of the research was chosen a sequence of amino acids of insulin of cat: alanine-valine-histidine-alanine

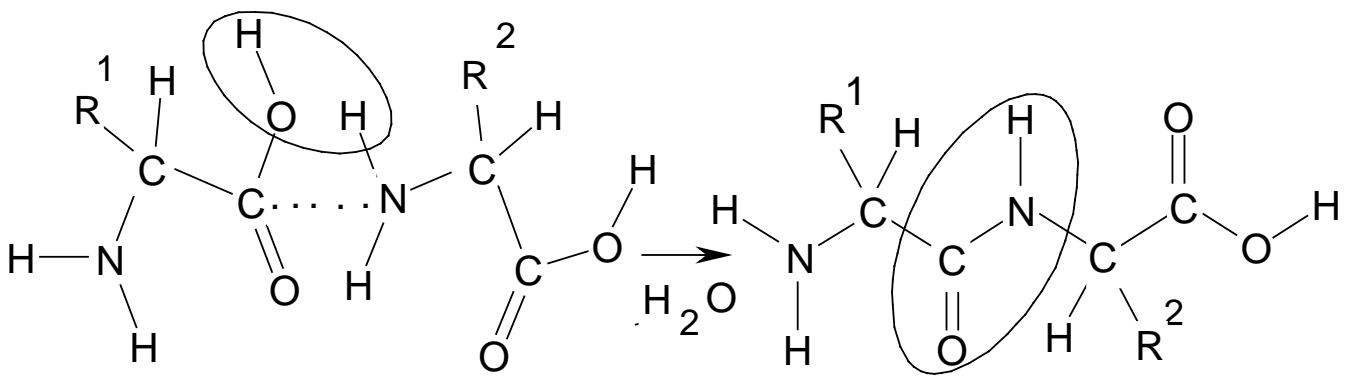


[13]. In this row only fourth amino acid are changed in species of others natural amino acids (see Table 1 ). The decrease of the $\mathrm{C}-\mathrm{O}$ and $\mathrm{N}-\mathrm{H}\left(\mathrm{P}_{\mathrm{CO}}, \mathrm{P}_{\mathrm{NH}}\right)$ bond orders and also values of energy of activation $\left(\Delta \mathrm{E}^{\#}\right)$, and the increase of the $\mathrm{O}-\mathrm{H}$ and $\mathrm{N}-\mathrm{C}$ bond orders $\left(\mathrm{P}_{\mathrm{OH}}, \mathrm{P}_{\mathrm{NC}}\right)$ and exothermic property $(\Delta \mathrm{E}<0)$ of formation of the peptide bonds there is an opportunity of the quantitative description of probability of a sequence of amino acids in proteins.

From the analysis of the tabular data, it is possible to make the conclusion, that the offered criterion, for transition state, mainly satisfies the avha (alanine, valine, histydine, alanine) sequence, what completely consent with the literary data [2]. Besides the high propensity to the peptide bond formation and for a sequence avhser (4) and avhoxylisin (12) is observed. On the other hand on the bases not suitable and high values of the bond orders and energetic characteristics the sequence avhglu (9), avhthr (10) and avhtrp (15) should not be realized.

\section{Conclusion}

The quantum-chemical model of the quantitative description of influence of the R-groups of amino acids on formation of the peptide bonds is constructed. It is shown, that decrease of the $\mathrm{CO}$ and $\mathrm{NH}$ bond orders $\left(\mathrm{P}_{\mathrm{CO}}\right.$ and $\left.\mathrm{P}_{\mathrm{NH}}\right)$ and increase of the $\mathrm{OH}$ and $\mathrm{CN}$ bond orders $\left(\mathrm{P}_{\mathrm{OH}}\right.$ and $\left.\mathrm{P}_{\mathrm{CN}}\right)$, and also decrease of energy of activation $\left(\Delta \mathrm{E}^{\#}\right)$ of the peptide bond formation and the exothermic property $(\Delta \mathrm{E}<0)$ of processes the propensity to formation of peptide bonds are promoted.

Table 1. The values of the energy of the activation $\left(\Delta \mathrm{E}^{\#}\right)$ and reaction $(\Delta \mathrm{E})$, and the orders $\mathrm{CO}, \mathrm{OH}, \mathrm{NH}$, and $\mathrm{NC}$ bonds $\left(\mathrm{P}_{\mathrm{OC}}\right.$, $\mathrm{P}_{\mathrm{OH}}, \mathrm{P}_{\mathrm{NH}}$, and $\left.\mathrm{P}_{\mathrm{NC}}\right)$.

\begin{tabular}{|c|c|c|c|c|c|c|c|c|c|c|c|c|c|c|c|}
\hline $\mathrm{N}$ & Peptide & $\begin{array}{c}\Delta \mathrm{E}^{\#} \\
\mathrm{~kJ} / \mathrm{mol}\end{array}$ & $\underset{\mathrm{kJ} / \mathrm{mol}}{\Delta \mathrm{E}}$ & $\begin{array}{c}\mathrm{P}^{1} \\
\mathrm{CO}\end{array}$ & $\begin{array}{c}\mathrm{P}^{1} \\
\mathrm{OH}\end{array}$ & $\begin{array}{c}\mathrm{P}^{1} \\
\mathrm{NH}\end{array}$ & $\begin{array}{c}\mathrm{P}^{1} \\
\mathrm{CN}\end{array}$ & $\begin{array}{l}\mathrm{P}^{*} \\
\mathrm{CO}\end{array}$ & $\begin{array}{c}\mathrm{P}^{*} \\
\mathrm{OH}\end{array}$ & $\begin{array}{c}\mathrm{P}^{*} \\
\mathrm{NH}\end{array}$ & $\begin{array}{c}\mathrm{P}^{*} \\
\mathrm{CN}\end{array}$ & $\begin{array}{c}\mathrm{P}^{2} \\
\mathrm{CO}\end{array}$ & $\begin{array}{c}\mathrm{P}^{2} \\
\mathrm{OH}\end{array}$ & $\begin{array}{c}\mathrm{P}^{2} \\
\mathrm{NH}\end{array}$ & $\begin{array}{c}\mathrm{P}^{2} \\
\mathrm{CN}\end{array}$ \\
\hline 1 & avhala & 10.5 & -16.3 & 0.86 & 0.21 & 0.68 & 0.57 & 0.68 & 0.43 & 0.44 & 0.77 & 0.48 & 0.70 & 0.19 & 0.99 \\
\hline 2 & avhgly & 24.5 & -72.2 & 0.85 & 0.15 & 0.75 & 0.52 & 0.72 & 0.30 & 0.57 & 0.71 & 0.48 & 0.70 & 0.19 & 1.03 \\
\hline 3 & avhasn & 11.8 & -16.8 & 0.83 & 0.14 & 0.76 & 0.48 & 0.81 & 0.18 & 0.71 & 0.51 & 0.44 & 0.58 & 0.28 & 0.89 \\
\hline 4 & avhser & 34.9 & -0.02 & 0.91 & 0.18 & 0.72 & 0.51 & 0.65 & 0.50 & 0.38 & 0.84 & 0.50 & 0.70 & 0.20 & 1.00 \\
\hline 5 & avhcys & 79.0 & -36.7 & 0.79 & 0.28 & 0.58 & 0.70 & 0.67 & 0.40 & 0.46 & 0.83 & 0.46 & 0.69 & 0.19 & 1.01 \\
\hline 6 & avhmet & 3.2 & -60.9 & 0.76 & 0.18 & 0.71 & 0.53 & 0.58 & 0.36 & 0.51 & 0.77 & 0.39 & 0.70 & 0.20 & 1.00 \\
\hline 7 & avhasp & 24.6 & -131.2 & 0.88 & 0.16 & 0.72 & 0.53 & 0.84 & 0.19 & 0.68 & 0.58 & 0.45 & 0.70 & 0.19 & 0.93 \\
\hline 8 & avhgln & 91.6 & -139.1 & 0.84 & 0.13 & 0.76 & 0.43 & 0.65 & 0.31 & 0.54 & 0.60 & 0.33 & 0.72 & 0.20 & 1.01 \\
\hline 9 & avhglu & 192.9 & 144.1 & 0.83 & 0.15 & 0.75 & 0.50 & 0.68 & 0.29 & 0.58 & 0.67 & 0.58 & 0.41 & 0.47 & 0.79 \\
\hline 10 & avhthr & 86.9 & 67.2 & 0.84 & 0.14 & 0.74 & 0.57 & 0.56 & 0.46 & 0.41 & 0.86 & 0.43 & 0.69 & 0.23 & 0.89 \\
\hline 11 & avhlys & 56.5 & -78.1 & 0.83 & 0.13 & 0.75 & 0.50 & 0.58 & 0.35 & 0.51 & 0.71 & 0.47 & 0.69 & 0.19 & 0.97 \\
\hline 12 & avhoxylys & 50.5 & -7.2 & 0.91 & 0.15 & 0.74 & 0.54 & 0.55 & 0.50 & 0.35 & 0.90 & 0.47 & 0.68 & 0.19 & 1.00 \\
\hline 13 & avhphe & 25.5 & -48.1 & 0.89 & 0.15 & 0.74 & 0.56 & 0.64 & 0.38 & 0.48 & 0.79 & 0.46 & 0.69 & 0.19 & 1.00 \\
\hline 14 & avhtyr & 10.9 & -7.0 & 0.79 & 0.28 & 0.58 & 0.60 & 0.67 & 0.42 & 0.44 & 0.74 & 0.45 & 0.69 & 0.18 & 0.97 \\
\hline 15 & avhtrp & 279.6 & 262.2 & 0.73 & 0.21 & 0.66 & 0.63 & 0.39 & 0.54 & 0.34 & 0.78 & 0.34 & 0.62 & 0.28 & 0.84 \\
\hline 16 & avhhis & 1.1 & -28.9 & 0.80 & 0.27 & 0.59 & 0.68 & 0.74 & 0.34 & 0.46 & 0.75 & 0.46 & 0.69 & 0.20 & 1.03 \\
\hline 17 & avhval & 2.1 & -22.9 & 0.79 & 0.28 & 0.61 & 0.62 & 0.68 & 0.42 & 0.48 & 0.76 & 0.48 & 0.71 & 0.20 & 0.98 \\
\hline 18 & avhleu & 28.4 & -60.7 & 0.86 & 0.11 & 0.79 & 0.42 & 0.77 & 0.22 & 0.64 & 0.61 & 0.46 & 0.69 & 0.19 & 0.97 \\
\hline 19 & avhileu & 13.2 & -157.6 & 0.83 & 0.14 & 0.75 & 0.54 & 0.77 & 0.17 & 0.70 & 0.60 & 0.50 & 0.69 & 0.18 & 0.97 \\
\hline 20 & avharg & 34.1 & -191.6 & 0.71 & 0.23 & 0.64 & 0.54 & 0.61 & 0.30 & 0.56 & 0.64 & 0.31 & 0.59 & 0.27 & 0.90 \\
\hline
\end{tabular}

$\mathrm{P}^{1}$ - basic state; $\mathrm{P}^{*}$ - transition state, $\mathrm{P}^{2}$ - final state. The objects of research chose quartets of amino acids: avhx, where $\mathrm{a}=\mathrm{alanine}, \mathrm{v}=\mathrm{valine}, \mathrm{h}=$ histidine and $\mathrm{x}$-others natural amino acids. 


\section{References}

[1] Sanger, F. (1952) The Arrangement of Amino Acids in Proteins. Advances in Protein Chemistry, 7, 1-67. http://dx.doi.org/10.1016/S0065-3233(08)60017-0

[2] Ganong, W.F. (Editor) (1989) Review of Medical Physiology Fourteenth Edition. Appleton \& Lange, Publishers.

[3] Sanger, F. and Thompson, E.O.P. (1953) The Amino-Acid Sequence in the Glycyl Chain of Insulin. I. The Identification of Lower Peptides from Partial Hydrolysates. Biochemical Journal, 53, 353-366.

[4] Sanger, F. and Thompson, E.O.P. (1953) The Amino-Acid Sequence in the Glycyl Chain of Insulin. II. The Investigation of Peptides from Enzymic Hydrolysates. Biochemical Journal, 53, 366-374.

[5] Sanger, F. and Thompson, E.O.P. (1952) The Inversion of a Dipeptide Sequence during Hydrolysis in Dilute acid. Biochimica et Biophysica Acta, 9, 225-226.

[6] Sanger, F. and Tuppy, H. (1951) The Amino-Acid Sequence in the Phenylalanyl Chain of Insulin. The Investigation of Peptides from Enzymic Hydrolysates. Biochemical Journal, 49, 481-490.

[7] Kohn, W., A.D., Becke, A.D. and Parr, R.D. (1996) Density Functional Theory of Electronic Structure. The Journal of Physical Chemistry, 100, 12974-12980. http://dx.doi.org/10.1021/jp960669l

[8] Trobro, S. and Aqvist, J. (2005) Mechanism of Peptide Bond Synthesis on the Ribosome. Proceedings of the National Academy of Sciences of the United States of America, 102, 12395-12400. http://dx.doi.org/10.1073/pnas.0504043102

[9] Becke, A.D. (1988) Density-Functional Exchange-Energy Approximation with Correct Asymptotic Behavior. Physical Review A, 38, 3098-3100. http://dx.doi.org/10.1103/PhysRevA.38.3098

[10] Lee, C., Wang, W. and Parr, R.G. (1988) Development of the Colle-Salvetti Correlation-Energy Formula into a Functional of the Electron Density. Physical Review B, 37, 785-789. http://dx.doi.org/10.1103/PhysRevB.37.785

[11] Perdew, J.P. and Wang, Y. (1992) Accurate and Simple Analytic Representation of the Electron-Gas Correlation Energy. Physical Review B, 45, 13244-13249. http://dx.doi.org/10.1103/PhysRevB.45.13244

[12] Laikov, D.N. and Ustynyuk, Yu.A. (2005) PRIPODA-04: A Qiantem-Chemical Program Suite. New Possibilities in the Study of Molecular Systems with the Application Parallel Computing. Russ. Chem. Bull., Int. Ed., 54, 820-826.

[13] Ganong, W. (1989) Review of Medical Physiology 1989, and Canine and Feline Endocrinology and Reproduction. 
Scientific Research Publishing (SCIRP) is one of the largest Open Access journal publishers. It is currently publishing more than 200 open access, online, peer-reviewed journals covering a wide range of academic disciplines. SCIRP serves the worldwide academic communities and contributes to the progress and application of science with its publication.

Other selected journals from SCIRP are listed as below. Submit your manuscript to us via either submit@scirp.org or Online Submission Portal.
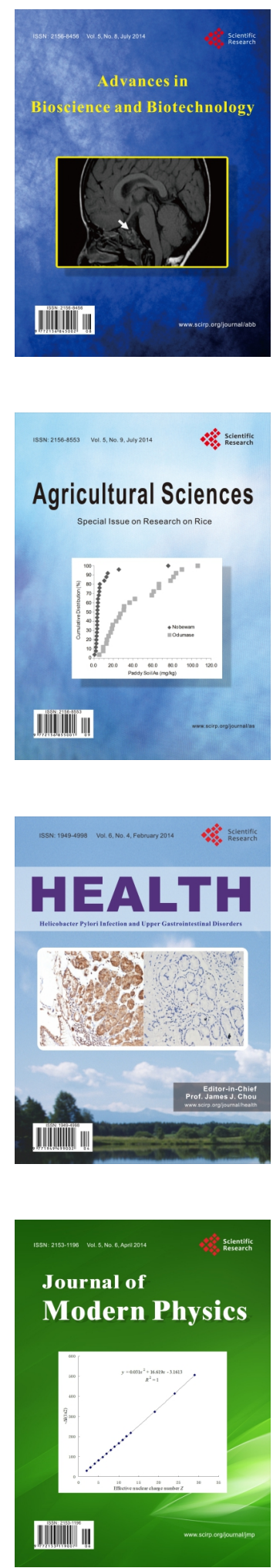
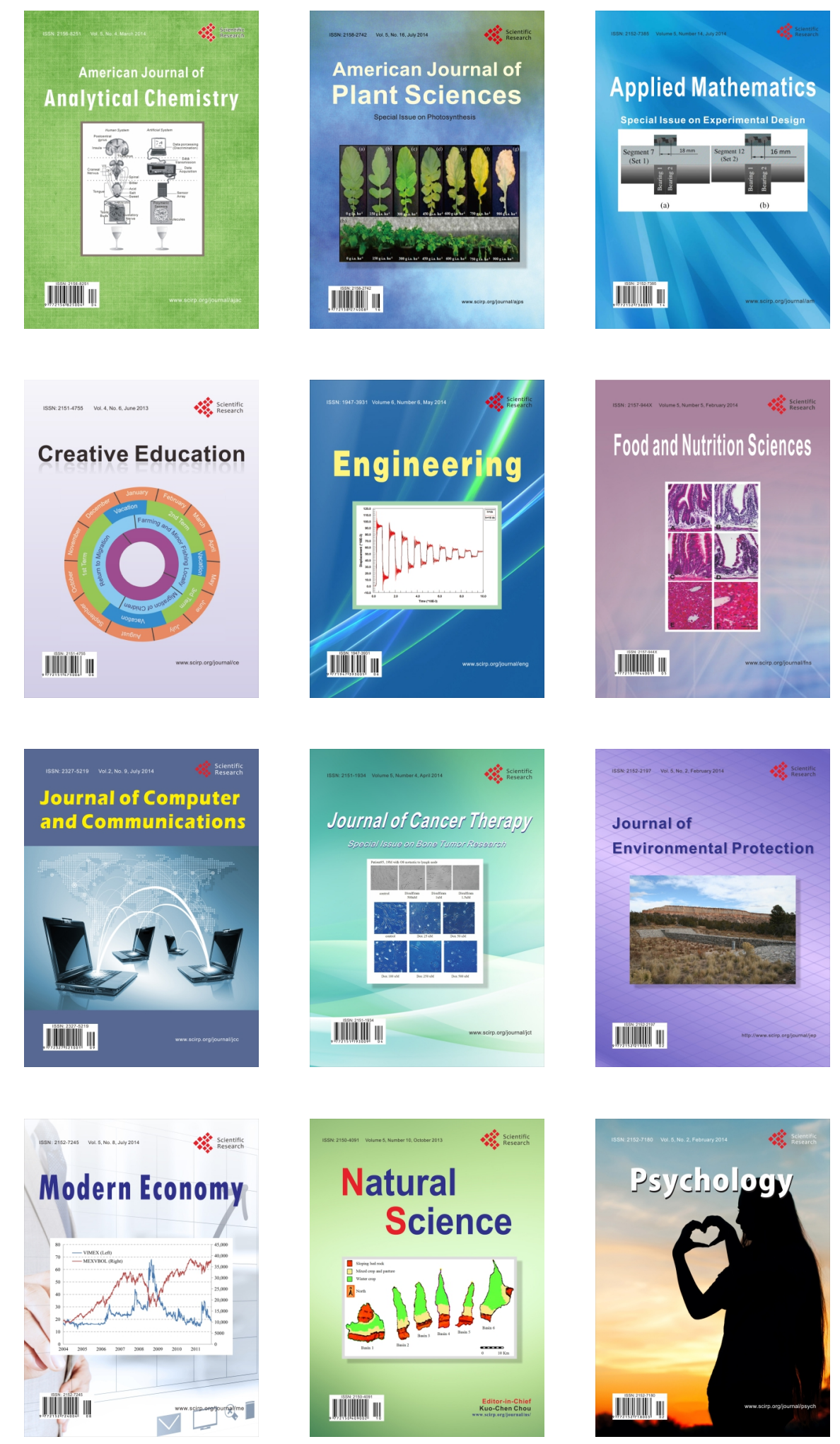